\title{
An Empirical Analysis of the Monetary Transmission Mechanism of Developing Economies: Evidence from Ghana
}

\author{
Felix S. Nyumuah ${ }^{1}$ \\ ${ }^{1}$ Department of Financial Management, Zenith University College, Accra, Ghana \\ Correspondence: Felix S. Nyumuah, P.O. Box SK 237, Sakumono Estates, Tema, Ghana. Tel: 233-243-671-295. \\ E-mail: fsnyumuah@yahoo.co.uk or silverglw7@gmail.com
}

Received: January 22, 2018

Accepted: February 19, $2018 \quad$ Online Published: February 28, 2018

doi:10.5539/ijef.v10n4p72

URL: https://doi.org/10.5539/ijef.v10n4p72

\begin{abstract}
Policymakers need a clear understanding of their monetary transmission mechanisms for effective implementation of monetary policy. The aim of this study is to carry out an econometric analysis of the channels of monetary transmission mechanism in less developed economies so as to determine their effectiveness. The study uses Ghana macroeconomic data and finds the money supply channel to be the strongest in the long run while the exchange rate channel seems the strongest in transmitting monetary impulses in the short run. The interest rate and the bank credit to private sector channels emerge as very weak channels of monetary transmission.
\end{abstract}

Keywords: monetary transmission mechanism, monetary policy, vector auto regression, variance decomposition

\section{Introduction}

Monetary policy is concerned with varying the money supply to influence the general price level and economic growth. Currently, there is much agreement about the supply of money affecting real output and the general level of prices. However, what still remains a dispute is the channels through which the money supply influences output and prices, that is, the monetary transmission mechanism. Policy makers need a clear understanding of the monetary transmission mechanism in order to accurately assess the timing and effect of policy measures on the economy. There are differences in these mechanisms among countries because of their different legal and financial structures (Aleem, 2010). Even though there have been a number of empirical studies of monetary transmission mechanisms in developing countries, structural and economic reforms being embarked upon by these economies necessitate an unrelenting study into their monetary transmission mechanisms. Hence, the purpose of this study is to carry out an econometric analysis of the various channels of monetary transmission mechanism, using data from a developing economy, and to determine the effectiveness of each channel.

Most investigations into monetary policy transmission mechanisms have looked at all the channels while very few studies have focused on specific channels of monetary transmission mechanism. Studies like Bernanke and Blinder (1992) and Bernanke and Gertler (1995) have looked at the transmission mechanism in the United States. Bernanke and Blinder (1992) present evidence in favour of the view that monetary policy works at least partly through credit (i.e bank loans) and partly through money (i.e bank deposits), while Bernanke and Gertler (1995) describe how the credit channel helps to explain the responses of Gross Domestic Product (GDP) and its components to monetary policy shocks. Aleem (2010) investigates the monetary policy transmission mechanism in India and finds banks to play a significant role in the transmission of monetary policy shocks to the real sector. Analysing for Brazil the implementation of monetary policy and the transmission channels, Montes (2013), found inflation targeting to be an effective tool in achieving macroeconomic stability. The study found that the expectations of entrepreneurs affect investment decisions and employment creation. It was also found that the expectations of entrepreneurs are affected by the traditional transmission channels.

Mishra, Montiel, Pedroni and Spilimbergo (2014) examine the transmission of monetary shocks to lending rates in a sample including low-income, emerging and advanced countries. They use a heterogeneous structural panel Vector Autoregressive (VAR) approach and find wide differences in the responses of bank lending rates to monetary policy innovations across countries. As is theoretically expected, low-income countries show much weaker transmission of monetary policy shocks to bank lending rates than do advanced and emerging economies. Ciccarelli, Maddaloni and Peydró (2015) investigate the credit channel of monetary transmission mechanism. 
They use United States and Euro area surveys and find that the credit channel increases a monetary policy shock on GDP and prices through the balance sheets of households, firms and banks.

Some other researchers have also used the time varying parameter vector autoregressive (TVP-VAR) model with stochastic volatility to investigate the monetary policy transmission mechanism. For example, Franta, Horvath and Rusnak (2014) conduct an investigation into the monetary policy transmission mechanism in the Czech Republic over the period 1996-2010 using the TVP-VAR model with stochastic volatility. They assess whether the response of the price level and GDP to interest rate and exchange rate shocks has varied over time. They find prices to be responsive to monetary policy shocks over the period and also show that the exchange rate channel has been stable over time. Simo-Kengne, Miller, Gupta and Balcilar (2016) find out whether the monetary transmission mechanism is captured by interest rate response to changes in asset returns. They also use a TVP-VAR approach with stochastic volatility, and with United States annual data covering the period 1890 to 2012, their results show that the interest rate reacts more strongly to asset returns during low-volatility regimes.

Finally, Mwabutwa, Viegi and Bittencourt (2016) examine the evolution of monetary transmission mechanism in Malawi using a TVP-VAR model with stochastic volatility over the period 1981 to 2010 . They evaluate how the responses of real output and general price level to bank rate, exchange rate and credit shocks have changed over time since Malawi embarked upon financial reforms in the 1980s. They find that inflation and real output responses to monetary policy shocks changed over the period under review. However, the statistical significance of the private credit supply remained weak despite the stable macroeconomic conditions and positive structural reforms in the country.

The monetary transmission mechanism literature has witnessed a change over the years. During the first three to four decades after World War II, economists adopted the IS-LM type aggregative macroeconomic model for analysing the role of monetary policy in economic stabilization. According to this framework, monetary policy could affect economy-wide aggregates such as real gross domestic product and the inflation rate. This was described as a 'black box' view, because it did not show what occurred in the interim when policy shocks are transmitted to the real economy (Bernanke \& Gertler, 1995). Hence, a section of the current literature is focused on disaggregated analysis of monetary policy. This tradition analyses the effect of monetary variables on the various components of aggregate demand like consumption and investment, trade and economic activities across firms, industries, sectors and regions within countries. For instance, Nwosa and Saibu (2012) examined the transmission channels of monetary policy impulses on sectoral output growth in Nigeria for the period 1986 to 2009. While the interest rate channel proved to be the most effective in transmitting monetary policy to Manufacturing and Agriculture sectors the exchange rate channel showed to be the most effective for transmitting monetary policy to Mining, Building and Construction, Service, Wholesale and Retail sectors. This tradition is influenced by the inspirational works on asymmetric information, market imperfection and moral hazard (Stiglitz \& Weiss, 1981), the bank credit channel comprising the balance sheet channel (Bernake \& Gertler, 1995) and the bank lending channel (Kashyap, Stein, \& Wilcox, 1993; Kashyap \& Stein, 1995).

As stated earlier on, understanding the monetary transmission mechanism is necessary for a successful monetary policy implementation. Furthermore, structural and economic reforms being initiated by developing economies demand continuous research into their transmission mechanisms. This study therefore contributes to the literature by providing current evidence on the nature of monetary transmission mechanisms in developing countries. It will also help policymakers to formulate effective monetary policy measures in their economies.

The primary aim of the study is to carry out econometric analyses of monetary transmission mechanisms of developing countries. Hence, the following three questions are addressed. First, does a change in the policy rate affect real output and the price level in developing economies? Second, which channels are the most effective in transmitting the impact of monetary policy to the economy? Finally, what length of time does it take the different channels to operate? To attain the goals of this study the monetary transmission mechanisms are analysed through the VAR framework.

The rest of the study is organised as follows: Section 2 describes the various channels of monetary transmission mechanisms while section 3 looks at the methodology. The results are presented in Section 4 and Section 5 concludes the study.

\section{Channels of Monetary Transmission Mechanism}

Meltzer (1995) defines monetary transmission mechanism as the means through which monetary policy decisions affect aggregate demand, real GDP, and the general level of prices. The channels through which monetary policy affects economic activities are usually identified in the literature as: (i) interest rate channel; (ii) money supply channel; (iii) exchange rate channel; (iv) asset price channel; (v) credit channel; and (vi) 
expectations channel.

\subsection{Interest Rate Channel}

In accordance with the Keynesian view, an increase in the money supply will cause real interest rate to fall due to sticky prices. This will result in a rise in investment spending and increases in aggregate demand and output. Mishkin (2006) also holds the view that an increase in the supply of money will cause the real interest rate to fall through the liquidity effect. The reduction in the cost of capital stimulates business investment and consumer spending on housing and durable goods. In a survey of empirical studies on the interest rate channel, Taylor (1995) found the interest rate channel to be a strong channel of monetary transmission mechanism.

\subsection{Money Supply Channel}

To the money supply view, a rise in the money supply increases bank reserves. This enhances the ability of banks to give more loans. The short term nominal interest rate is lowered, and with rational expectations, the short term real interest rate also falls. Thus, the reduction in the interest rate will increase aggregate investment and output.

\subsection{Exchange Rate Channel}

In open economies the exchange rate also plays a key role in transmitting the effects of monetary policy. An expansionary monetary policy causes the domestic real interest rate to fall. Assets which are denominated in the domestic currency, therefore, become less attractive than assets denominated in foreign currencies, causing a depreciation of the domestic currency. The depreciation of the domestic currency makes domestic goods relatively cheaper than foreign goods, and consequently causing net exports and output to rise (Mishkin, 2006).

\subsection{Asset Price Channel}

Apart from interest rates and exchange rates, other asset prices like equity and real estate also play a role in the monetary transmission mechanism. This channel applies the Tobin's Q theory. Tobin (1969) defined the Q as the ratio of the market value of a firm to the replacement cost of capital owned by that firm. In Tobin's view, an expansionary monetary policy increases the demand for equities. Rising equity prices boosts market value of firms relative to the replacement cost of capital. As a result, there will be an increase in investment and output. This view is further reinforced by Modigliani's life cycle model, which asserts that a rise in financial wealth increases households' consumption (Mishkin 2006, 2001).

\subsection{Credit Channel}

The credit channel arose because of dissatisfaction over explaining the effects of monetary policy on durables expenditure and investment through interest rate effects. According to Mishkin (1995) the credit channel explains the impact of monetary policy through the effects of informational asymmetry between the lender and the borrower. These informational asymmetries give rise to two channels of monetary transmission mechanism: the bank lending channel and the balance sheet channel.

The bank lending channel operates through the effect of monetary policy on the supply of bank loans rather than the interest rate, that is, the quantity rather than the price of credit. An expansion in the money supply increases the excess reserves in the banking system. This increases the supply of loans. Increased supply of loans leads to increased investment as well as consumption spending which result in increased economic activity.

The balance-sheet channel operates through the net worth of firms. An expansionary monetary policy increases the value of assets and reduces business costs through lower interest rates, which increases the net worth of firms. The reduction in interest rates also decreases the debt servicing burden of firms and households. This improves the cash flow of firms and thus enhances their chances of accessing loans from banks. The increase in net worth of firms reduces the possibility of moral hazard and adverse selection. The consequence is increased borrowing leading to increased consumer spending and investment and economic activity.

\subsection{Expectations Channel}

There is a consensus among economists that expectations influence economic activity. According to the expectations channel monetary policy measures affect the economy by influencing the expectations of economic agents regarding the future of the economy. Monetary transmission channels may be improved by the expectation effects through the shortening of reaction lags (Mayes, 2004). Economic agents expectations about future changes in the policy rate can instantly affect medium and long-term interest rates. Monetary policy can be used to influence expectations of future inflation. Inflation expectations affect price and real interest rate levels, and feed through into actual inflation in later periods. Also, changes in attitude towards monetary policy can affect expectations about the future course of real economic activities by influencing inflationary expectations and the ex-ante real interest rate and thereby controlling the future direction of economic activities. 


\section{The Empirical Methodology}

The objective of the study is to carry out an empirical investigation into the monetary transmission mechanism of developing countries using data from a typical developing country, Ghana. The focus is on the Money Supply channel, Exchange Rate channel, Credit channel and the Interest Rate channel which is signified by the Policy Rate channel. With respect to methodology the Granger causality tests, variance decompositions, and impulse response functions are used to investigate the effect of the various shocks on output and inflation.

\subsection{Modelling}

The common model used in the literature for an empirical investigation into the monetary transmission mechanism is the VAR model. The study employs a six-variable $\operatorname{VAR}(\mathrm{P})$ (or a p-th order vector autoregression) model specified as follows:

$$
\begin{array}{lll}
\mathrm{R}_{\mathrm{t}}=\text { Policy rate } & \mathrm{M}_{\mathrm{t}}=\text { Money Supply } & \mathrm{L}_{\mathrm{t}}=\text { Bank Credit to Private Sector } \\
\mathrm{E}_{\mathrm{t}}=\text { Exchange rate } & \mathrm{Q}_{\mathrm{t}}=\text { Real output } & \mathrm{P}_{\mathrm{t}}=\text { Consumer price index }
\end{array}
$$

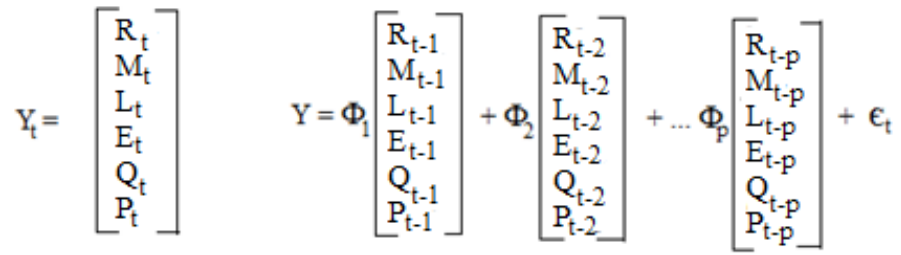

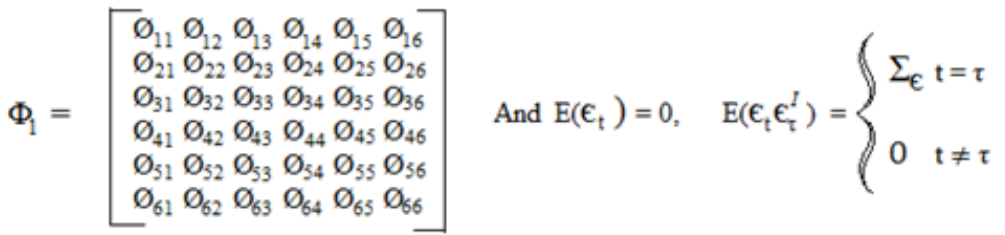

The model can be represented in general form using the lag operator as follows:

$$
\left[I_{m}-\Phi_{1} L-\Phi_{2} L^{2}-\ldots-\Phi_{p} L^{p}\right] Y_{t}=\epsilon_{t}
$$

or

$$
\Phi(L) Y_{t}=\epsilon_{t}
$$

where $\Phi(\mathrm{L})=\mathrm{I}_{\mathrm{m}}-\Phi_{1} \mathrm{~L}-\Phi_{2} \mathrm{~L}^{2}-\ldots-\Phi_{\mathrm{p}} \mathrm{L}^{\mathrm{p}}$ is the lag polynomial of order $\mathrm{p}$ with $\mathrm{m} \mathrm{x}$ m coefficient matrices $\Phi_{\mathrm{i}}, \mathrm{i}$ $=1$, p.

If the covariance-stationarity holds then the inverse $\Phi^{-1}(\mathrm{~L})$ exists. Premultiplying equation (1) by $\Phi^{-1}(\mathrm{~L})$, we get

$$
Y_{t}=\psi(L) \epsilon_{t}
$$

where $\Phi^{-1}(\mathrm{~L})=\psi(\mathrm{L})=\mathrm{I}_{\mathrm{m}}+\psi_{1} \mathrm{~L}+\psi_{2} \mathrm{~L}^{2}+$

Impulse responses trace out the response of current and future values of each of the variables to a one-unit increase in the current value of one of the VAR errors.

From the above analysis,

$$
\begin{gathered}
\Phi(\mathrm{L}) \mathrm{Y}_{\mathrm{t}}=\mathrm{Y}_{\mathrm{t}}-\Phi_{1} \mathrm{Y}_{\mathrm{t}-1}-\Phi_{2} \mathrm{Y}_{\mathrm{t}-2}-\ldots-\Phi_{\mathrm{p}} \mathrm{Y}_{\mathrm{t}-\mathrm{p}} \quad \text { and } \\
\Phi^{-1}(\mathrm{~L}) \epsilon_{\mathrm{t}}=\psi(\mathrm{L}) \epsilon_{\mathrm{t}}=\epsilon_{\mathrm{t}}+\psi_{1} \epsilon_{\mathrm{t}-1}+\psi_{2} \epsilon_{\mathrm{t}-2}+\ldots \ldots \ldots \ldots \ldots
\end{gathered}
$$

Our model can be expressed as

$$
\mathrm{Y}_{\mathrm{t}}=\epsilon_{t}+\sum_{i=1}^{\infty} \Psi_{i} \epsilon_{t-\mathrm{i}}
$$

Expressing the future value of $Y_{t}$ as $Y_{t+n}$

$$
\mathrm{Y}_{t+n}=\epsilon_{t+n}+\sum_{i=1}^{\infty} \Psi_{i} \epsilon_{t^{+n-i}}
$$


The effect of a unit change in $\epsilon_{\mathrm{t}}$ on $\mathrm{Y}_{\mathrm{t}+\mathrm{n}}$ is

$$
\frac{\partial Y_{t+n}}{\partial \epsilon_{t}}=\Psi_{n} .
$$

The $\epsilon_{\mathrm{t}}$ 's represent shocks in the system, therefore the $\psi_{\mathrm{i}}$ matrices represent the model's response to a unit shock (or innovation) at time $t$ in each of the variables i periods ahead.

The response of $Y_{i}$ to a unit change in $Y_{j}$ is therefore given by the sequence below, known as the impulse response function,

$$
\psi_{i j, 1}, \psi_{i j, 2}, \psi_{i j, 3}, \ldots
$$

where $\psi_{\mathrm{ij}, \mathrm{k}}$ is the ijth element of the matrix $\psi_{\mathrm{k}}(\mathrm{i}, \mathrm{j}=1, \ldots, \mathrm{m})$.

The innovations $\epsilon_{\mathrm{t}}$ are usually correlated. Impulse response analysis does not make sense if the correlations are high. A transformation is therefore applied so that the shocks become orthogonal or uncorrelated and have a unit variance. There are many ways of achieving orthogonalisation. In deriving orthogonal shocks to the endogenous variables, researchers of monetary transmission mechanism often depend on Cholesky factorization which involves a lower triangular variance-covariance matrix of VAR residuals.

Consider the VAR model,

$$
\mathrm{Y}_{\mathrm{t}}=\psi(\mathrm{L}) \epsilon_{\mathrm{t}} \text { with } \mathrm{E}\left(\epsilon_{\mathrm{t}} \epsilon_{\mathrm{t}}^{I}\right)=\Sigma_{\epsilon}
$$

The orthogonalised impulse response coefficients can be obtained by letting $\mathrm{S}$ be the Cholesky decomposition of the residual covariance matrix $\Sigma_{\epsilon}$ such that,

$$
\Sigma_{\epsilon}=\mathrm{SS}^{\mathrm{I}}
$$

We can write

$$
\begin{aligned}
\mathrm{Y}_{\mathrm{t}} & =\sum_{i=0}^{\infty} \Psi_{i} \epsilon_{t-i} \\
& =\sum_{i=0}^{\infty} \Psi_{i} \mathrm{SS}^{-1} \epsilon_{t-i} \\
& =\sum_{i=0}^{\infty} \Psi_{i}^{*} \nu_{t-i},
\end{aligned}
$$

where $\psi_{\mathrm{i}}^{*}=\psi_{\mathrm{i}} \mathrm{S}$ and $v_{\mathrm{t}}=\mathrm{S}^{-1} \epsilon_{\mathrm{t}}$

Then $\operatorname{Cov}\left(v_{\mathrm{t}}\right)=\mathrm{E}\left(v_{\mathrm{t}} v_{\mathrm{t}}^{\mathrm{I}}\right)=\mathrm{E}\left(\mathrm{S}^{-1} \epsilon_{\mathrm{t}} \epsilon_{\mathrm{t}}^{\mathrm{I}} \mathrm{S}^{-1 I}\right)=\mathrm{E}\left(\mathrm{S}^{-1} \Sigma_{\mathrm{t}} \mathrm{S}^{I-1}\right)=\mathrm{S}^{-1} \mathrm{E}\left(\epsilon_{\mathrm{t}} \epsilon_{\mathrm{t}}^{I}\right) \mathrm{S}^{I-1}=\mathrm{S}^{-1} \Sigma_{\mathrm{c}} \mathrm{S}^{I-1}=\mathrm{I}$

Therefore, the conditions for orthogonalised impulse response functions are fulfilled.

The new model can be represented as

$$
\mathrm{Y}_{t}=\Psi^{*}(L) \nu_{t}=\sum_{i=0}^{\infty} \psi_{i}^{*} \nu_{t-i},
$$

Where $\psi_{i}^{*}=\psi_{i} S$

The impulse response function of $Y_{i}$ to a unit shock $Y_{j}$ is given by the orthogonalised impulse response function

$$
\psi_{i j, 0}^{*}, \psi_{i j, 1}^{*}, \psi_{i j, 2}^{*}, \ldots \text {. }
$$

\subsubsection{Cholesky Decomposition and Ordering of Variables}

Cholesky decomposition of $\Sigma_{\epsilon}$ results in a lower triangular matrix with positive main diagonal elements for $\psi_{0}{ }^{*}$, for example

$$
\left(\begin{array}{l}
\mathrm{Y}_{1, t} \\
\mathrm{Y}_{2, t}
\end{array}\right)=\left(\begin{array}{cc}
\psi_{11}^{*(0)} & 0 \\
\psi_{21}^{*}(0) & \psi_{22}^{*(0)}
\end{array}\right)\left(\begin{array}{l}
\nu_{1, t} \\
\nu_{2, t}
\end{array}\right)+\psi^{*}(1) \nu_{t-1}+\ldots
$$

This implies that the second shock $v_{2, t}$ does not affect the first variable $Y_{1, t}$ contemporaneously, but both shocks can have contemporaneous effect on $\mathrm{Y}_{2, \mathrm{t}}$ (and all following variables, if we had chosen an example with more than two components). Hence the ordering of the variables is important.

It is recommended that the first variable should be selected such that it is the only one with potential immediate impact on all other variables. The second variable may have an immediate impact on the last m-2 components of 
$\mathrm{Y}_{\mathrm{t}}$, but not on $\mathrm{Y}_{1 \mathrm{t}}$, the first component, and so on.

\subsubsection{Variance Decomposition}

Because the shocks $v_{t}$ 's are uncorrelated and have unit variances the error variance of the forecast of $Y_{i t}$ can be decomposed into component shocks accounted for by innovations to $Y_{j}$ as follows:

Consider an orthogonalised VAR with m components,

$$
\mathrm{Y}_{\mathrm{t}}=\sum_{l=0}^{\infty} \psi^{*}(l) \nu_{t-l}
$$

The $n$ step-ahead forecast for $\mathrm{Y}_{\mathrm{t}}$ will be

$$
\mathrm{E}_{t}\left(\mathrm{Y}_{t+n}\right)=\sum_{l=n}^{\infty} \psi^{*}(l) \nu_{t+n-l} .
$$

The associated forecast error can be stated as

$$
\mathbf{e}_{t+n}=\mathrm{Y}_{t+n}-\mathrm{E}_{t}\left(\mathrm{Y}_{t+n}\right)
$$

giving

$$
\mathbf{e}_{t+n}=\sum_{l=0}^{n-1} \psi^{*}(l) \nu_{t+n-l}
$$

It's $i$ 'th component will be

$$
e_{i, t+n}=\sum_{l=0}^{n-1} \sum_{j=1}^{m} \psi_{i j}^{*(l)} \nu_{j, t+n-l}=\sum_{j=1}^{m} \sum_{l=0}^{n-1} \psi_{i j}^{*(l)} \nu_{j, t+n-l} .
$$

Since the shocks are both serially and contemporaneously uncorrelated, the error variance becomes

$$
\begin{aligned}
\mathbf{V}\left(e_{i, t+n}\right) & =\sum_{j=1}^{m} \sum_{l=0}^{n-1} \mathbf{V}\left(\psi_{i j}^{*(l)} \nu_{j, t+n-l}\right) \\
& =\sum_{j=1}^{m} \sum_{l=0}^{n-1} \psi_{i j}^{*(l)^{2}} \mathbf{V}\left(\nu_{j, t+n-l}\right) .
\end{aligned}
$$

With all shock components having unit variance, we get

$$
\mathbf{V}\left(e_{i, t+s}\right)=\sum_{j=1}^{m}\left(\sum_{l=0}^{s-1} \psi_{i j}^{*(l)^{2}}\right)
$$

where $\sum_{l=0}^{n-1} \psi_{i j}^{*(l)^{2}}$ is the error variance generated by innovations to $\mathrm{Y}_{\mathrm{j}}$

The relative importance of each random variable $\mathrm{j}$ innovation in explaining the variation in variable $i$ at different step-ahead forecasts is given as a percentage as

$$
R_{i j, l}^{2}=100 \frac{\sum_{l=0}^{n-1} \psi_{i j}^{*(l)^{2}}}{\sum_{k=1}^{m} \sum_{l=0}^{n-1} \psi_{i k}^{*(l)^{2}}} .
$$

The impulse response functions trace the effects of a shock to one endogenous variable on the other variables in the VAR. Variance decomposition separates the variation in an endogenous variable into the component shocks of the VAR and thus provides information about the relative importance of each random innovation in affecting the variables in the VAR.

\subsubsection{Granger Causality}

If we consider a bivariate VAR system of two variables $z_{t}$ and $x_{t}$. If $x_{t}$ does not Granger cause $z_{t}$ then 


$$
\begin{aligned}
\left(\begin{array}{c}
z_{t} \\
x_{t}
\end{array}\right)= & \left(\begin{array}{ll}
\phi_{11}^{(1)} & 0 \\
\phi_{21}^{(1)} & \phi_{22}^{(1)}
\end{array}\right)\left(\begin{array}{c}
z_{t-1} \\
x_{t-1}
\end{array}\right)+\cdots \\
& +\left(\begin{array}{cc}
\phi_{11}^{(p)} & 0 \\
\phi_{21}^{(p)} & \phi_{22}^{(p)}
\end{array}\right)\left(\begin{array}{c}
z_{t-p} \\
x_{t-p}
\end{array}\right)+\left(\begin{array}{c}
\epsilon_{1, t} \\
\epsilon_{2, t}
\end{array}\right) .
\end{aligned}
$$

Which gives

$$
\left(\begin{array}{c}
z t \\
x_{t}
\end{array}\right)=\left(\begin{array}{c}
\epsilon_{1, t} \\
\epsilon_{2, t}
\end{array}\right)+\sum_{i=1}^{\infty}\left(\begin{array}{cc}
\psi_{11}^{(i)} & 0 \\
\psi_{21}^{(i)} & \psi_{22}^{(i)}
\end{array}\right)\left(\begin{array}{c}
\epsilon_{1, t-i} \\
\epsilon_{2, t-i}
\end{array}\right)
$$

This can be represented as

$$
\mathrm{Y}_{\mathrm{t}}=\epsilon_{t}+\sum_{i=1}^{\infty} \Psi_{i} \epsilon_{t-i}
$$

where the coefficient matrices $\psi_{j}=\sum_{i=1}^{j} \psi_{j-i} \Phi_{i}$ are lower triangular.

With the lower triangular matrices, it is obvious that the variable $\mathrm{z}$ does not react to shocks in $\mathrm{x}$. Hence $\mathrm{x}$ does not Granger cause z. Granger causality does not indicate causality in the more common use of the term, but answers the question as to whether past and current values of $\mathrm{x}$ can help to predict the future values of $\mathrm{z}$. To accomplish the aims of the study, Granger causality among the variables is tested.

\subsection{Data and Choice of Variables}

The study employs quarterly data from 1990 to 2015. The sources of data are the Bank of Ghana website for the money supply (M2); the International Financial Statistics of the International Monetary Fund for the policy rate $(\mathrm{R})$, the exchange rate $(\mathrm{E})$ and the consumer price index used as a proxy for the price level $(\mathrm{P})$; and World Bank Development Indicators for real output $(\mathrm{Q})$ and bank credit to the private sector $(\mathrm{L})$. The data on real output or real Gross Domestic Product and bank credit to the private sector are recorded on an annual basis only. Therefore, quarterly time series are generated from the samples by converting low frequency data to high frequency data in EViews using the constant-match average method.

Ghana has adopted an inflation targeting policy regime with the policy rate as the main tool for controlling inflation. The variables are entered into the VAR equation in the following order, R, M2, L, E, Q and P. The ordering of the variables is based on the assumption that changes to the policy rate will give shocks to the money supply and through the credit and exchange rate channels affect output and prices. The consumer price index is used as a proxy for the price level. The broad money variable M2 is chosen as the money supply because broad money is the intermediate target for formulating and implementing monetary policy in Ghana.

\section{Empirical Results}

This section analyses the monetary transmission mechanism using the Granger causality tests in Table 2, variance decompositions in Tables 3 and 4, and the impulse response functions in Figure 1 in the Appendix. Prior to carrying out the analysis the lag length selection criteria is used to select the optimal lag length. The results presented in Table 1 show that the optimal lag length is eight lags using the Likelihood Ratio (LR) test, the Final Prediction Error (FPE), and the Akaike Information Criterion (AIC). The Schwarz criterion indicates four lags whilst the Hannan-Quinn criterion (HQ) selects five lags. Consequently, eight lags are considered in making the analysis. 
Table 1. VAR lag order selection criteria

\begin{tabular}{ccccccc}
\hline Lag & LogL & LR & FPE & AIC & SC & HQ \\
\hline 0 & -2663.674 & NA & $5.75 \mathrm{E}+16$ & 55.61822 & 55.77849 & 55.683 \\
1 & -1853.333 & 1502.508 & $5.68 \mathrm{E}+09$ & 39.4861 & 40.608 & 39.93959 \\
2 & -1708.631 & 250.2133 & $5.95 \mathrm{E}+08$ & 37.22148 & 39.30502 & 38.06368 \\
3 & -1615.272 & 149.7644 & $1.84 \mathrm{E}+08$ & 36.02649 & 39.07166 & 37.2574 \\
4 & -1505.562 & 162.2788 & 41337387 & 34.49088 & $38.49767^{*}$ & 36.11049 \\
5 & -1443.36 & 84.23257 & 25687810 & 33.94499 & 38.91342 & $35.95331^{*}$ \\
6 & -1405.489 & 46.54901 & 27525736 & 33.90602 & 39.83608 & 36.30305 \\
7 & -1352.264 & 58.76983 & 22521689 & 33.54716 & 40.43885 & 36.33289 \\
8 & -1290.511 & $60.46662^{*}$ & $16483827^{*}$ & $33.01064^{*}$ & 40.86395 & 36.18507 \\
\hline
\end{tabular}

* indicates lag order selected by the criterion.

LR: sequential modified LR test statistic (each test at $5 \%$ level);

FPE: Final prediction error;

AIC: Akaike information criterion;

SC: Schwarz information criterion;

HQ: Hannan-Quinn information criterion.

The Granger causality tests in Table 2 indicate that money supply Granger causes exchange rate, output and prices at both the 5\% and 10\% levels of significance but does not Granger cause credit. On the other hand, credit Granger causes the money supply and output but does not Granger cause prices. The exchange rate Granger causes money supply and prices but does not Granger cause output. Surprisingly, the policy rate does not Granger cause any of the variables, however credit Granger causes the policy rate.

Table 2. Granger causality tests, $\mathrm{p}$-values for the ${ }^{\chi 2}$ Tests.

\begin{tabular}{cccccccc}
\hline Dependent Var. & \multicolumn{9}{c}{ Excluded Variable(s) } \\
\cline { 2 - 8 } & $\mathrm{R}$ & $\mathrm{M} 2$ & $\mathrm{~L}$ & $\mathrm{E}$ & $\mathrm{Q}$ & $\mathrm{P}$ & All \\
\hline R & --- & 0.7559 & 0.2622 & 0.7261 & 0.3512 & 0.7008 & 0.4153 \\
M2 & 0.8832 & --- & 0.3212 & 0.0000 & 0.0000 & 0.0000 & 0.0000 \\
L & 0.0075 & 0.0428 & --- & 0.7867 & 0.0056 & 0.1235 & 0.0753 \\
E & 0.6937 & 0.0000 & 0.6838 & --- & 0.8118 & 0.0000 & 0.0000 \\
Q & 0.9145 & 0.0003 & 0.1659 & 0.1570 & -- & 0.0003 & 0.0000 \\
P & 0.7011 & 0.3607 & 0.2355 & 0.0000 & 0.0191 & -- & 0.0000 \\
\hline
\end{tabular}

Variance decomposition of output $(\mathrm{Q})$ and prices $(\mathrm{P})$ is carried out to look at the strengths of the channels of monetary transmission mechanism. This is achieved by using forecast horizons of four through 44 quarters. One quarter ahead is the short run and four, eight and 12 quarters represent the medium term, while 20 quarters ahead is the long run. The first column lists the quarters ahead, whereas the second column refers to standard error (SE), which is the forecast error of the variable at different quarters. Variables are ordered in the same way they appear in the Table. That is, the third column refers to R, the fourth M2, the fifth L, the sixth E, the seventh $\mathrm{Q}$ and the last P. Table 3 below, which presents the variance decomposition of $\mathrm{Q}$, shows that money supply and the exchange rate are important sources of shocks in output in comparison to $\mathrm{R}$, and $\mathrm{L}$. In the short run shocks in the exchange rate are important sources of fluctuations in output while the money supply plays a more dominant role in the long run accounting for about $33 \%$ of the shocks in output. Over the medium term, shocks in the exchange rate were more influential than shocks in the money supply after four quarters; accounting for $24.84 \%$ of shocks in output. In the $8^{\text {th }}$ and 12 th quarters, the money supply became the more influential source. However, the exchange rate reemerged in the $16^{\text {th }}$ quarter as more important in explaining output variability, accounting for $18.17 \%$ of the shocks in output. Shocks in R accounted for only 1 to $4 \%$ of the shocks to output and shocks in $\mathrm{L}$ explained about 2 to $8 \%$ of the variability in output. This means the effects of the interest rate and credit channels were insignificant.

The results of the variance decomposition of price $(\mathrm{P})$ are presented in Table 4. In the short and medium term the exchange rate was more responsible for explaining the variability in prices than R, M2 and L. However, in the long run, the influence of the exchange rate declined from $27.23 \%$ to $24.25 \%$ while that of the money supply rose from $22.83 \%$ to $30.5 \%$. Thus the money supply emerged as the most influential source of variability in the 
price level in the long run. The policy rate accounted for 2 to $4 \%$ of the variability in the price level while bank credit to the private sector contributed 2 to $8 \%$ of the shock in prices. This demonstrates the weakness of the interest rate and credit channels in influencing the price level.

Table 3. Variance decomposition of output (Q)

\begin{tabular}{cccccccc}
\hline Quarters ahead & S.E. & $\mathrm{R}$ & $\mathrm{M} 2$ & $\mathrm{~L}$ & $\mathrm{E}$ & $\mathrm{Q}$ & $\mathrm{P}$ \\
\hline 1 & 208.7073 & 1.643767 & 0.736664 & 2.790706 & 11.40134 & 83.42752 & 0.0000 \\
4 & 369.2294 & 1.066601 & 18.32225 & 6.895985 & 24.83797 & 34.35564 & 14.52156 \\
8 & 560.7954 & 1.261156 & 19.72666 & 5.499998 & 17.796 & 35.04944 & 20.66674 \\
12 & 677.368 & 4.456921 & 18.05938 & 5.602514 & 16.72263 & 32.28109 & 22.87747 \\
16 & 938.8319 & 5.929784 & 16.37464 & 5.634786 & 18.46524 & 20.40366 & 33.19189 \\
20 & 1543.339 & 4.878871 & 21.25164 & 5.749958 & 20.71831 & 11.27823 & 36.123 \\
24 & 3035.327 & 4.305165 & 28.64545 & 6.869859 & 21.53236 & 7.478813 & 31.16836 \\
28 & 6884.578 & 4.22109 & 32.34182 & 7.534228 & 21.33431 & 6.256725 & 28.31183 \\
32 & 16175.14 & 4.098458 & 33.07277 & 7.833116 & 21.54698 & 6.13083 & 27.31785 \\
36 & 38167.32 & 4.064478 & 33.27571 & 8.009191 & 21.75894 & 6.174716 & 26.71696 \\
40 & 89911.65 & 4.100878 & 33.59309 & 8.08263 & 21.70301 & 6.217726 & 26.30266 \\
44 & 211810.9 & 4.137311 & 33.81786 & 8.123191 & 21.65534 & 6.236499 & 26.0298 \\
\hline
\end{tabular}

Cholesky Ordering: R M2 LE Q P.

Table 4. Variance decomposition of price $(\mathrm{P})$

\begin{tabular}{cccccccc}
\hline Quarters ahead & S.E. & $\mathrm{R}$ & $\mathrm{M} 2$ & $\mathrm{~L}$ & $\mathrm{E}$ & $\mathrm{Q}$ & $\mathrm{P}$ \\
\hline 1 & 0.794831 & 4.509192 & 0.015094 & 2.94728 & 5.039616 & 1.265963 & 86.22286 \\
4 & 1.990173 & 4.807159 & 0.943921 & 6.141318 & 25.39712 & 0.815413 & 61.89507 \\
8 & 3.248094 & 2.400515 & 2.796503 & 8.328825 & 32.03257 & 0.621906 & 53.81968 \\
12 & 4.619937 & 3.219332 & 11.11684 & 7.955587 & 27.28681 & 1.465668 & 48.95576 \\
16 & 7.84066 & 3.599246 & 19.61298 & 7.522175 & 24.55739 & 5.385218 & 39.323 \\
20 & 16.75507 & 3.237335 & 22.83013 & 7.169588 & 27.22597 & 6.243627 & 33.29335 \\
24 & 37.96916 & 3.701984 & 27.88992 & 6.984345 & 26.08576 & 5.776205 & 29.56179 \\
28 & 88.17434 & 3.801479 & 29.73143 & 7.015852 & 25.30135 & 5.621383 & 28.52851 \\
32 & 207.9531 & 3.702764 & 29.93214 & 7.03299 & 24.95993 & 5.548537 & 28.82363 \\
36 & 491.8289 & 3.660883 & 30.06485 & 7.08192 & 24.74269 & 5.584702 & 28.86495 \\
40 & 1160.372 & 3.666231 & 30.29298 & 7.116793 & 24.49328 & 5.64787 & 28.78284 \\
44 & 2735.098 & 3.680357 & 30.51144 & 7.137014 & 24.25073 & 5.68553 & 28.73493 \\
\hline
\end{tabular}

Cholesky Ordering: R M2 LE Q P.

We can confirm further the effects of shocks on output and prices by looking at the impulse responses in Figure 1 in the Appendix. The shocks are represented by one standard deviation of the error term in the specified model for the variables. The first pair of graphs in Figure 1 show the response of output to shocks in R and M2. A shock to the policy rate has virtually no effect on output over the 20-year horizon while a shock to the money supply also yields no impact on output until $70^{\text {th }}$ quarter after which it begins to have a little influence on it. The second pair of graphs also depict the responses of output to shocks in L and E. Both shocks appear to exert no influence on the level of output until the $70^{\text {th }}$ quarter when they begin to have a little impact on it. Price level responses to shocks in R, M2, L and E are shown in the fourth and fifth pairs of graphs. The price level responses appear to be similar in nature to those of output. A one-standard deviation shock to the policy rate yields almost no impact on the price level while a shock to the money supply has no effect until the $70^{\text {th }}$ quarter when it begins to have a little effect. Shocks to $\mathrm{L}$ and $\mathrm{E}$ have no impact on the price level up to the $70^{\text {th }}$ quarter and thereafter begin to exert some little influence on it.

Impulse response analysis does not make sense if correlations between the VAR residuals are high. The analysis will be valid if shocks are serially and contemporaneously uncorrelated. To test the robustness of the results the correlation matrix of the reduced-form VAR residuals based on the ordering of variables, which were entered into the VAR. is obtained. This is shown in Table 5 below. The low correlation coefficients means that the contemporaneous feedback is not a problem. 
Table 5. Correlation matrix of reduced-form residuals

\begin{tabular}{ccccccc}
\hline & $\mathrm{R}$ & $\mathrm{M} 2$ & $\mathrm{~L}$ & $\mathrm{E}$ & $\mathrm{Q}$ & $\mathrm{P}$ \\
\hline $\mathrm{R}$ & 1 & -0.0916439 & -0.2478884 & -0.0453698 & 0.1282095 & 0.2123486 \\
$\mathrm{M} 2$ & 1 & -0.0697098 & -0.0188894 & 0.0737184 & -0.0072265 \\
$\mathrm{~L}$ & & 1 & 0.23423083 & -0.2008437 & 0.111774 \\
$\mathrm{E}$ & & & 1 & -0.3742948 & 0.2476218 \\
$\mathrm{Q}$ & & & & & 1 & 0.0265687 \\
$\mathrm{P}$ & & & & & & 1 \\
\hline
\end{tabular}

\section{Summary and Conclusion}

This study examines monetary transmission mechanisms in developing countries using Ghana macroeconomic data. The objective is to examine the relationships between the monetary policy rate and key macroeconomic variables and find out how quickly and the extent to which changes in the central bank's interest rate instrument influence output and inflation. The empirical investigation covers a 26-year period (1990-2015) and focuses on four channels of monetary transmission, namely, policy rate or interest rate (R), money supply (M2), bank credit to private sector (L), and exchange rate (E) channels. Using quarterly data and employing Granger causality tests, variance decomposition and impulse response analyses, the empirical findings reveal that the policy rate does not Granger cause any of the variables and none of the variables Granger causes it apart from bank credit to the private sector. The money supply channel appears to be the strongest in the long run while the exchange rate channel emerges the strongest of transmitting monetary impulses in the short run. The policy rate or interest rate channel and the bank credit to private sector channel are however very weak channels of monetary transmission mechanism.

These findings bring to the fore the means through which the impact of monetary policy is transmitted to the economies of developing countries and thus provides insights into the nature of monetary policy transmission mechanisms in such economies. The findings have some policy implications. The weak interest rate and bank credit to private sector transmission channels means inflation targeting monetary policy will be ineffective in achieving macroeconomic stability. Other instruments like quantitative targets, reserve requirements and taxing of excess reserves would have to be used. Institutional and financial reforms should therefore be intensified in order to reduce information asymmetries, improve property rights and contract enforcement. This will increase banks willingness to lend to the private sector. It is expected that these findings would be useful in monetary policy making in developing countries. However, the study has some limitations in that other channels of transmission, like the asset price channel and the expectations channel were not considered. To achieve a complete assessment of monetary transmission mechanisms in developing economies, further research must examine these channels also as the financial sectors of developing countries continue to develop.

\section{References}

Aleem, A. (2010). Transmission mechanism of monetary policy in India. Journal of Asian Economics, 21, 186-197. https://doi.org/10.1016/j.asieco.2009.10.001

Bernanke, B., \& Blinder, A. S. (1992). The Federal Funds Rate and the Channels of Monetary Transmission. American Economic Review, 82(4), 901-921.

Bernanke, B., \& Gertler, M. (1995). Inside the Black Box: The Credit Channel of Monetary Policy Transmission. The Journal of Economic Perspectives, 9(4), 27-48. https://doi.org/10.1257/jep.9.4.27

Ciccarelli, M., Maddaloni, A., \& Peydró , J. (2015). Trusting the Bankers: A New Look at the Credit Channel of

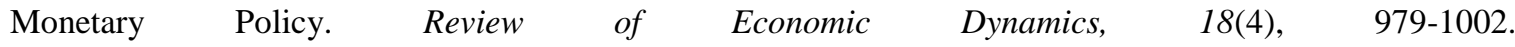
https://doi.org/10.1016/j.red.2014.11.002

Franta, M., Horvath, R., \& Rusnak, M. (2014). Evaluating Changes in the Monetary Transmission Mechanism in the Czech Republic. Empirical Economics, 46(3), 827-842. https://doi.org/10.1007/s00181-013-0699-0

Kashyap, A. K., \& Stein, J. C. (1995). The Impact of Monetary Policy on Bank Balance Sheets. $\begin{array}{llllll}\text { Carnegie-Rochester Conference } & \text { Series }\end{array}$ https://doi.org/10.1016/0167-2231(95)00032-U

Kashyap, A. K., Stein, J. \& Wilcox, D. W. (1993). Monetary Policy and Credit Conditions: Evidence from the Composition of External Finance. American Economic Review, 83(1).

Mayes, D. (2004). The Monetary Transmission Mechanism in the Baltic States. Talinin: Bank of Estonia. 
Meltzer, A. H. (1995). Monetary, credit and other transmission process. Journal of Economic Perspectives, 9, 3-10. https://doi.org/10.1257/jep.9.4.49

Mishkin, F. (1995). Symposium on the Monetary Transmission Mechanism. The Journal of Economic Perspectives, 9(4), 3-10. https://doi.org/10.1257/jep.9.4.3

Mishkin, F. (2001). The Transmission Mechanism and the Role of Asset Prices. NBER Working Paper 8617, Cambridge, Mass: National Bureau of Economic Research

Mishkin, F. (2006). The Economics of Money, Banking, and Financial Markets (8th ed.). Addison Wesley, Boston.

Mishra, P., Montiel, P., Pedroni, P., \& Spilimbergo, A. (2014). Monetary Policy and Bank Lending Rates in Low-income Countries: Heterogeneous Panel Estimates. Journal of Development Economics, 111, 117-131. https://doi.org/10.1016/j.jdeveco.2014.08.005

Montes, G. C. (2013). Credibility and monetary transmission channels under inflation targeting: An econometric analysis from a developing country. Economic Modelling, 30, 670-684. https://doi.org/10.1016/j.econmod.2012.09.035

Mwabutwa, C. N., Viegi, N., \& Bittencourt, M. (2016). Evolution of Monetary Policy Transmission Mechanism in Malawi: A TPV-VAR Approach. Journal of Economic Development, 41(1).

Nwosa, P. I., \& Saibu, M. O. (2012). The Monetary Transmission Mechanism in Nigeria: A Sectoral Output Analysis. International Journal of Economics and Finance, 4(1).

Simo-Kengne, B. D., Miller, S. M., Gupta, R., \& Balcilar, M. (2016). Evolution of the Monetary Transmission Mechanism in the US: The Role of Asset Returns. The Journal of Real Estate Finance and Economics, 52(3), 226-243. https://doi.org/10.1007/s11146-015-9512-5

Stiglitz, J., \& Weiss, A. (1981). Credit Rationing in Markets with Imperfect Information. American Economic Review, 71, 393-410.

Taylor, J. (1995). The Monetary Transmission Mechanism: An Empirical Framework. The Journal of Economic Perspectives, 9(4), 11-26. https://doi.org/10.1257/jep.9.4.11

Tobin, J. (1969). A General Equilibrium Approach to Monetary Theory. Journal of Money, Credit, and Banking, 1, 15-29. https://doi.org/10.2307/1991374

\section{Appendix}

Response to Cholesky One S.D. Innovations \pm 2 S.E.
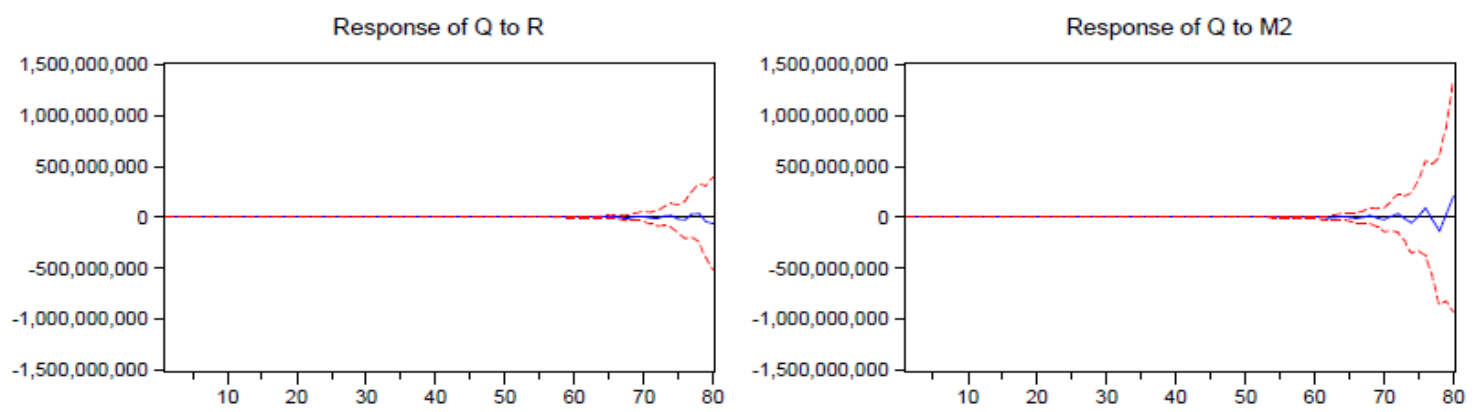

Response of $Q$ to $L$
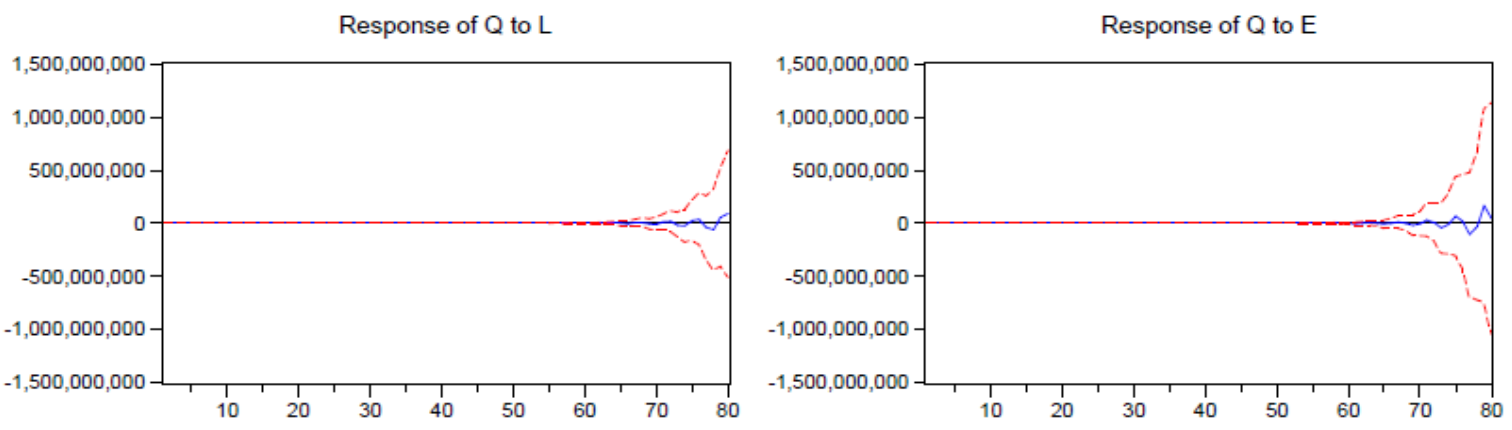
Response of $\mathrm{Q}$ to $\mathrm{Q}$

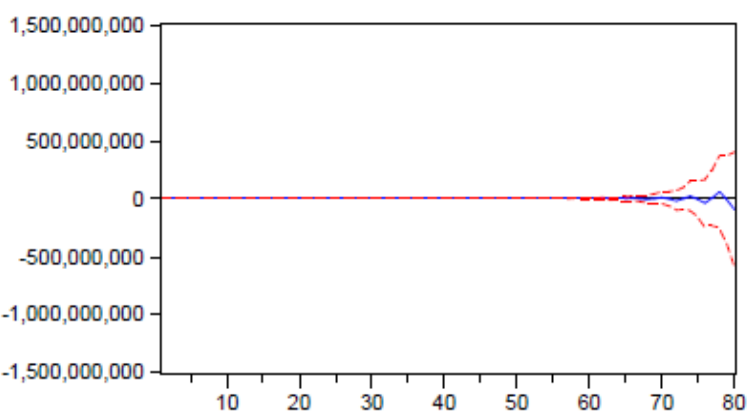

Response of $\mathrm{P}$ to $\mathrm{R}$

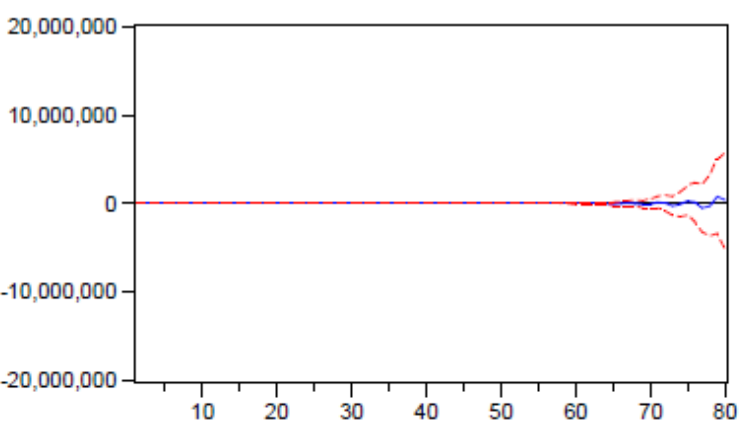

Response of $\mathrm{P}$ to $\mathrm{L}$

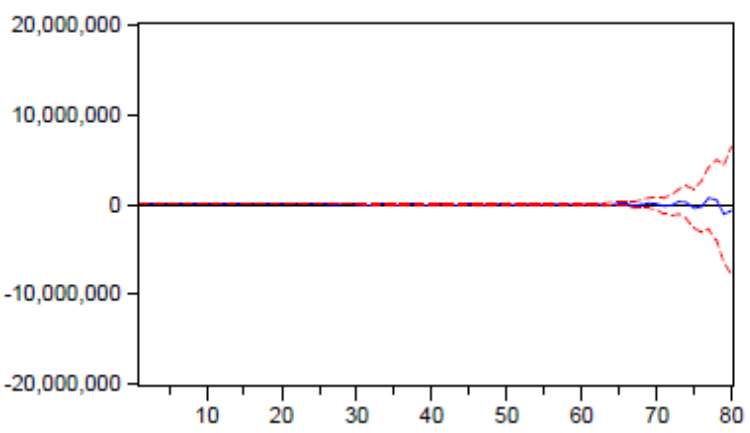

Response of $\mathrm{P}$ to $\mathrm{Q}$

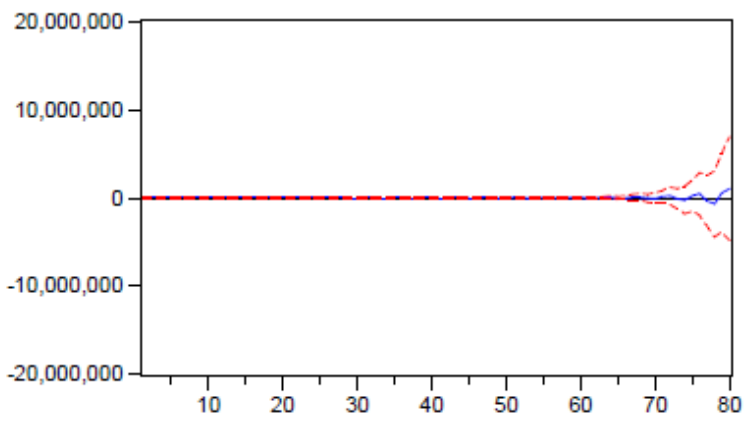

Response of $Q$ to $P$

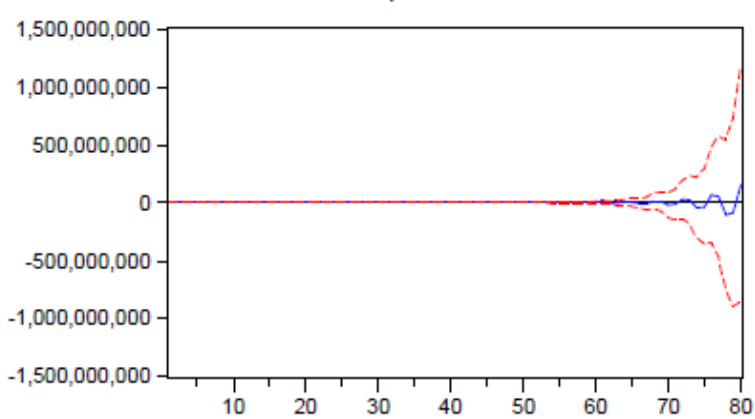

Response of $\mathrm{P}$ to $\mathrm{M} 2$

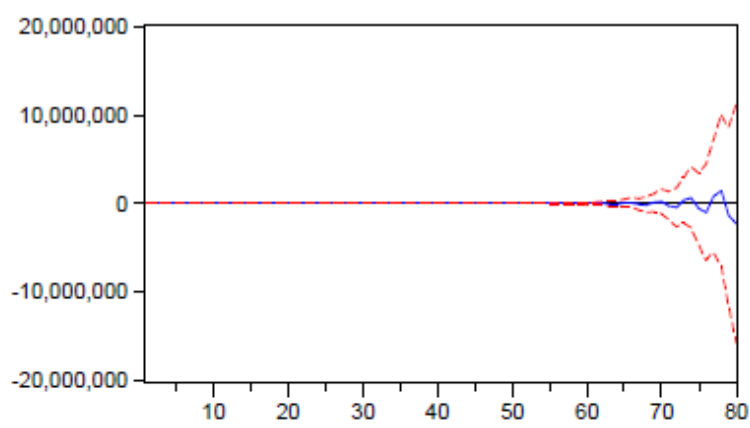

Response of $\mathrm{P}$ to $\mathrm{E}$

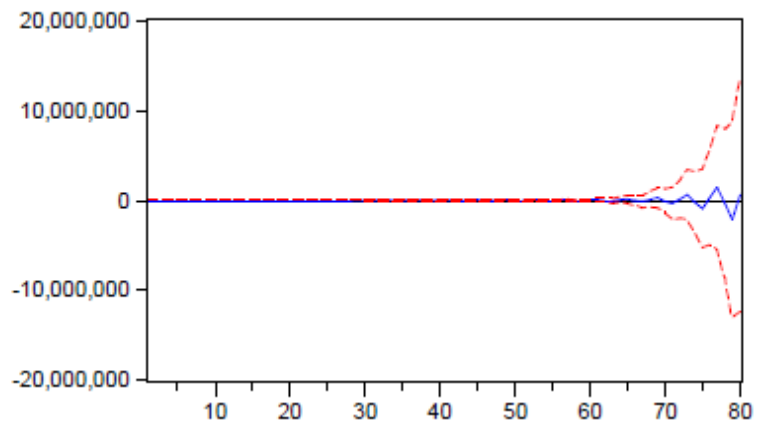

Response of $\mathrm{P}$ to $\mathrm{P}$

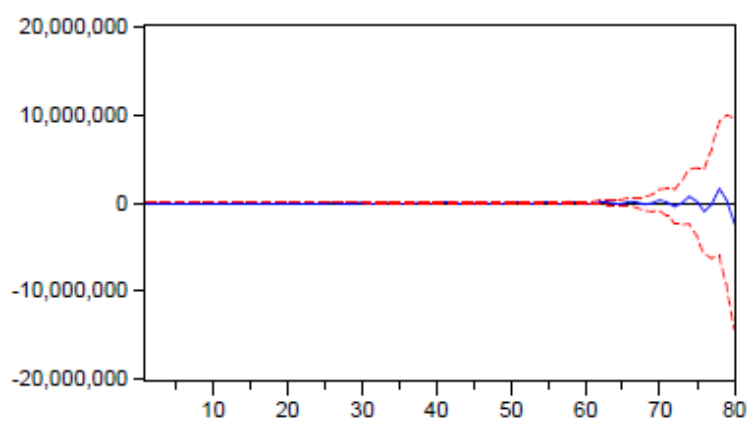

Figure 1. Impulse response functions

\section{Copyrights}

Copyright for this article is retained by the author(s), with first publication rights granted to the journal.

This is an open-access article distributed under the terms and conditions of the Creative Commons Attribution license (http://creativecommons.org/licenses/by/4.0/). 